\title{
EPT Larangan Penerimaan Titipan Sertifikat Hak Atas Tanah oleh Notaris danKaitannya dengan Kode Etik Notaris
}

\author{
Rika Kumala Sari Rimba \\ Program Magister Kenotariatan Fakultas Hukum Universitas Lambung Mangkurat, \\ Jalan Brigjend H. Hasan Basry, Banjarmasin 70123, Indonesia \\ Telp/Fax: +62 511 3307877, Email : sesiliarika@gmail.com
}

Diterima: 08/07/2016; Revisi: 13/09/2016; Disetujui: 23/09/2016

\begin{abstract}
Notary public is one of legal profession which has a code of ethics conduct made by the Indonesian Notary Public Association. This code of conduct is aimed at keep the behaviors of the Notary Public in performing their profession. A Notary Public must respect and hold in high esteem the dignity of the position of Notary Public, to keep and defend the honor of the association. But, in fact, a Notary Public often takes risks in performing his/ her office, namely, by receiving deposit of certificate of land right of the parties. The aim of this research is to know the prohibition to receive deposit of certificate of land right by the Notary Public and to know the relation between the said prohibition and the code of conduct of Notary Public. This research is normative legal research. The type of the research is to elaborate the vacuum of regulation in Act Number 30 of 2004 concerning Position of Notary Public, Act Number 02 of 2014 concerning Amendment to Act Number 30 of 2004 and Code of Conduct of the Indonesia Notary Public Association, namely, concerning the problem to receive deposit of certificate of land right by the Notary Public. The characteristic of this research is descriptive.
\end{abstract}

KeyWords : code of ethics, Prohibition, Certificate of Land Right, Notary Public,,

\begin{abstract}
Abstrak: Notaris merupakan salah satu profesi hukum yang mempunyai kode etik yang dibuat oleh Ikatan Notaris Indonesia. Adanya kode etik notaris bertujuan untuk menjaga perilaku notaris dalam menjalankan jabatannya. Dalam menjalankan jabatannya, notaris harus menghormati dan menjunjung tinggi harkat dan martabat jabatan notaris, menjaga dan membela kehormatan perkumpulan. Tetapi, dalam kenyataannya notaris sering melakukan hal yang beresiko dalam menjalankan jabatannya, yaitu dengan menerima penitipan sertifikat hak atas tanah dari para pihak. Tujuan dari penelitian untuk mengetahui larangan penerimaan titipan sertifikat hak atas tanah oleh notaris dan mengetahui hubungan keterkaitan antara larangan penerimaan titipan sertifikat hak atas tanah oleh notaris dengan
\end{abstract}


kode etik notaris. Penelitian ini merupakan penelitian hukum normatif. Tipe penelitian: penelitian terhadap kekosongan hukum dalam Undang-Undang Nomor 30 Tahun 2004 tentang Jabatan Notaris, Undang-Undang Nomor 02 Tahun 2014 tentang Perubahan Atas Undang-Undang Nomor 30 Tahun 2004 tentang Jabatan Notaris dan Kode Etik Notaris Ikatan Notaris Indonesia (I.N.I), yaitu mengenai masalah penerimaan titipan tanda bukti hak kepemilikan atas tanah para pihak oleh notaris. Sifat penelitian dalam penulisan tesis ini bersifat deskriptif.

Kata-kata kunci : kode etik. larangan, sertifikat hak atas tanah, notaris

\section{PENDAHULUAN}

Notaris merupakan salah satu profesi yang sangat dibutuhkan oleh masyarakat umum pada saat ini. Menurut Undang-Undang Nomor 30 Tahun 2004 tentang Jabatan Notaris selanjutnya disebut Undang-Undang Jabatan Notaris. Pasal 1 poin 1, yang dimaksud dengan notaris adalah pejabat umum yang berwenang untuk membuat akta otentik dan kewenangan lainnya sebagaimana dimaksud dalam undang-undang ini. Sebagai sebuah profesi, notaris mempunyai kode etik tersendiri untuk dijadikan sebagai pegangan dalam bertindak dalam melakukan setiap pekerjaannya. Kode etik notaris dibuat oleh organisasi notaris yaitu Ikatan Notaris Indonesia (INI) dan isinya banyak bersumber dari Undang-Undang Nomor 30 Tahun 2004 tentang Jabatan Notaris.

Menurut Ikatan Notaris Indonesia, pengertian kode etik notaris adalah : "Kode Etik Notaris dan untuk selanjutnya disebut Kode Etik adalah seluruh kaidah moral yang ditentukan oleh Perkumpulan Ikatan Notaris Indonesia yang selanjutnya akan disebut "Perkumpulan" berdasar keputusan Kongres Perkumpulan dan/atau yang ditentukan oleh dan diatur dalam peraturan perundangundangan yang mengatur tentang hal itu dan Perkumpulan dan semua orang yang menjalankan tugas jabatan sebagai Notaris, termasuk di dalamnya para Pejabat Sementara
Notaris, Notaris Pengganti dan Notaris Pengganti Khusus."

Adapun kode etik ini berlaku bagi seluruh anggota perkumpulan maupun orang lain yang memangku dan menjalankan jabatan Notaris baik dalam pelaksanaan jabatan maupun dalam kehidupan sehari-hari.

Kode etik notaris dibuat untuk menjaga kehormatan dan keluhuran martabat jabatan notaris. Kode etik notaris memuat kaidah moral yang wajib ditaati oleh setiap anggota perkumpulan yang telah diatur, baik dalam Staatsblad 1860 Nomor 3 maupun dalam Pasal 89 Undang-Undang Nomor 30 Tahun 2004 tentang Jabatan Notaris berikut sanksi-sanksi yang akan diberikan bila anggota melakukan pelanggaran. ${ }^{1}$ Maka dari itu, setiap anggota notaris haruslah memahami setiap peraturanperaturan yang dibuat didalam kode etik notaris.

Dalam Pasal 3 Kode Etik Notaris Ikatan Notaris Indonesia (I.N.I) menyebutkan bahwa salah satu kewajiban notaris dalam memangku dan menjalankan jabatannya adalah menghormati dan menjunjung tinggi harkat dan martabat jabatan notaris, menjaga dan membela kehormatan perkumpulan. Tetapi, dalam kenyataannya, notaris sering secara

1 Fitria Anggraeni. Etika Profesi Seorang Notaris. www.academia.edu/ 6276509/BAB_I MAKALAH_NOTARIS. Diakses pada tanggal 02/06/2015. 
sadar maupun tidak sadar sering melakukan hal-hal yang melanggar isi pasal tersebut. Terjadinya pelanggaran kode etik notaris oleh notaris disebabkan oleh beberapa kepentingan, baik itu kepentingan diri sendiri maupun kepentingan orang-orang disekitarnya.

Hal yang paling sering dilakukan oleh notaris adalah dengan menerima penitipan sertifikat hak atas tanah dari para pihak. Padahal, hal tersebut merupakan perbuatan yang beresiko dan dapat membuat notaris melakukan hal-hal yang dapat melanggar kode etik notaris. Larangan perbuatan notaris untuk menerima penitipan sertifikat hak atas tanah dari para pihak juga secara tersirat terdapat dalam pasal 52 ayat (1) Undang-Undang Nomor 30 Tahun 2004 tentang Jabatan Notaris yang menyebutkan bahwa "Notaris tidak diperkenankan membuat akta untuk diri sendiri, istri/suami, atau orang lain yang mempunyai hubungan kekeluargaan dengan notaris baik karena perkawinan maupun hubungan darah dalam garis keturunan lurus ke bawah dan/atau ke atas tanpa pembatas derajat, serta dalam garis ke samping sampai dengan derajat ketiga, serta menjadi pihak untuk diri sendiri, maupun dalam suatu kedudukan ataupun perantaraan kuasa."

Dari pernyataan diatas, dapat diketahui bahwa notaris dilarang untuk menjadi pihak yang terlibat dalam akta yang dibuatnya sendiri. Hal ini bertujuan agar akta yang dibuat benarbenar murni tidak hanya menguntungkan salah satu pihak saja dalam akta tersebut, karena disini kedudukan notaris adalah netral, tidak membuat akta hanya untuk keuntungan salah satu pihak saja.

Perbuatan notaris yang menerima titipan dari para pihak tersebut juga berkaitan dengan kode etik notaris, karena kode etik notaris lah yang mengatur bagaimana seorang notaris itu bertindak dalam menjalankan jabatannya. Di dalam kode etik notaris di Indonesia memang belum ada menyebutkan secara tegas dan tertulis apakah notaris boleh menerima titipan tanda bukti kepemilikan para pihak atau tidak. Hal ini menyebabkan masih banyak notaris yang berani untuk menerima titipan sertifikat hak atas tanah tersebut, karena menganggap perbuatan tersebut merupakan perbuatan yang diperbolehkan. Banyak notaris yang belum sadar mengenai resiko yang akan ditanggung melalui menerima penitipan sertifikat hak atas tanah dari para pihak tersebut. Tetapi ada juga beberapa notaris yang menolak untuk menerima penitipan sertifikat hak atas tanah dari para pihak untuk menghindari resiko yang mungkin akan terjadi dikemudian hari.

Penerimaan penitipan sertifikat hak atas tanah dari para pihak oleh notaris memang dapat menimbulkan resiko dikemudian hari. Resiko tersebut dapat terjadi karena adanya maksud tidak baik dari salah satu pihak, baik dari pihak yang menitipkan sertifikat hak atas tanah tersebut atau pihak yang menerima titipan sertifikat hak atas tanah tersebut. Hal ini tentu saja dapat menimbulkan kerugian bagi para pihak atau bagi notaris yang menerima penitipan sertifikat hak atas tanah tersebut.

\section{RUMUSAN MASALAH}

1. Bagaimana peraturan tentang larangan penerimaan titipan sertifikat hak atas tanah oleh notaris?

2. Bagaimana hubungan keterkaitan antara larangan penerimaan titipan sertifikat hak atas tanah oleh notaris dengan kode etik notaris?

\section{METODE PENELITIAN}

\section{JENIS PENELITIAN}


Jenis penelitian yang digunakan adalah penelitian hukum normatif, yaitu jenis penelitian hukum yang dilakukan dengan cara meneliti bahan hukum primer dan bahan hukum sekunder.

\section{TIPE PENELITIAN}

Tipe penelitian yang digunakan penulis adalah meneliti adanya kekaburan hukum dalam Kode Etik Notaris Ikatan Notaris Indonesia (I.N.I), Undang-Undang Nomor 30 Tahun 2004 tentang Jabatan Notaris, dan Undang-Undang Nomor 02 Tahun 2014 tentang Perubahan Atas Undang-Undang Nomor 30 Tahun 2004 tentang Jabatan Notaris.

\section{SIFAT PENELITIAN}

Sifat penelitian yang digunakan yaitu bersifat deskriptif, dimana hasil kajian terhadap peraturan perundang-undangan dan bahan hukum lainnya yang diuraikan dan digambarkan secara rinci sehingga permasalahan hukum yang dikemukakan.

\section{JENIS DAN SUMBER BAHAN HUKUM}

a. Bahan hukum primer, yaitu berupa peraturan perundang-undangan yang berlaku dan ada kaitannya dengan objek penelitian serta penelitian yang dibahas, dalam hal ini terdiri dari:

1) Kitab Undang-Undang Hukum Perdata (KUHPerdata).

2) Undang-Undang Nomor 30 Tahun 2004 tentang Jabatan Notaris.

3) Undang-Undang Nomor 02 Tahun 2014 tentang Perubahan Atas Undang-Undang Nomor 30 Tahun 2004 tentang Jabatan Notaris.

4) Peraturan Pemerintah Nomor 40 Tahun 1996 tentang Hak Guna Usaha, Hak Guna Bangunan, dan Hak Pakai atas Tanah.
5) Peraturan Pemerintah Nomor 24 Tahun 1997 tentang Pendaftaran Tanah.

b. Bahan hukum sekunder, yaitu bahan hukum yang diperoleh dari buku, tesis, diktat, jurnal dan internet khususnya di bidang sertifikat tanah, penitipan barang, kode etik notaris serta sumber-sumber lain yang mendukung penelitian ini.

c. Bahan non hukum, merupakan inf-ormasi yang diberikan oleh informan yaitu dari notaris yang penulis minta informasinya.

\section{TEKNIK PENGUMPULAN BAH-AN HUKUM}

a. Bahan hukum primer diinventaris-asi dari berbagai peraturan perundang-undangan yang relevan dengan pokok bahasan, kemudian diolah dan dianalisis secara sistematis.

b. Bahan hukum sekunder dikumpulkan dari buku-buku, majalah, tulisan-tulisan para ahli hukum, dan tulisan-tulisan para sarjana khususnya di bidang jabatan notaris, kode etik notaris, sertifikat tanah, penitipan barang dan ilmu-ilmu lainnya yang berhubungan baik secara langsung maupun tidak langsung dengan pokok bahasan yang diangkat.

c. Bahan non hukum melalui wawancara pribadi kepada informan yang memberikan informasi tentang kode etik notaris dan akta otentik notaris.

\section{PENGOLAHAN DAN ANALISIS BAHAN HUKUM}

Dalam penelitian ini penulis mengolah bahan hukum dengan cara berpikir sistematis. Pengolahan dan analisis bahan hukum yang penulis lakukan pertama-tama adalah dengan mengumpulkan bahan hukum, baik itu 
bahan hukum primer maupun bahan hukum sekunder. Setelah semua bahan dikumpulkan, kemudian penulis mulai menganalisis bahan hukum tersebut yang hanya berkaitan dengan permasalahan yang dibahas. Langkah terakhir, setelah penulis melakukan analisis maka bahan-bahan hukum tersebut dihubungkan satu sama lain sehingga pada akhirnya penulis menemukan sebuah kesimpulan yang berisikan jawaban dari permasalahan yang sedang dibahas.

\section{HASIL PENELITIANDAN PEMBAHASAN}

\section{A. PERATURAN TENTANG LARANG- AN PENERIMAAN TITIPAN SERTIFIKAT HAK ATAS TANAH OLEH NOTARIS}

\section{Larangan Penerimaan Titipan} Sertifikat Hak atas Tanah oleh Notaris berdasarkan Peraturan yang Berlaku.

Di dalam Undang-Undang Nomor 30 Tahun 2004 tentang Jabatan Notaris dan Undang-Undang Nomor 02 Tahun 2014 tentang Perubahan Atas Undang-Undang Nomor 30 Tahun 2004 tentang Jabatan Notaris mengenai kewajiban notaris, tidak ada disebutkan secara bahwa notaris berkewajiban menerima titipan sertifikat hak atas tanah dari para pihak. Tetapi di dalam undang-undang tersebut juga tidak ada pasal yang melarang untuk notaris menerima titipan sertifikat hak atas tanah. Kekaburan hukum mengenai boleh atau tidaknya notaris menerima titipan sertifikat hak atas tanah inilah yang membuat perbedaan pendapat diantara beberapa notaris. Ada yang berpendapat bahwa notaris tidak boleh sama sekali menerima penitipan sertifikat hak atas tanah dari para pihak, karena hal itu merupakan beban bagi notaris itu sendiri. Ada juga yang berpendapat bahwa notaris boleh menerima titipan sertifikat hak atas tanah dari para pihak, selama sertifikat tersebut berkaitan dengan akta yang sedang diurus oleh notaris tersebut.

Sementara itu, dilihat dari kewenangan notaris yang diatur dalam undang-undang yang berlaku, notaris hanya berwenang melakukan beberapa hal seperti yang disebutkan dalam Pas-al 15 Undang-Undang Nomor 02 Tahun 2014 tentang Perubahan Atas Undang-Undang Nomor 30 Tahun 2004 tentang Jabatan Notaris. Tetapi, dalam Pasal 15 UndangUndang Nomor 02 Tahun 2014 tentang Perubahan Atas Undang-Undang Nomor 30 Tahun 2004 tentang Jabatan Notaris tidak ada satu pun pasal yang menyatakan bahwa notaris berwenang untuk menerima titipan sertifikat dari para pihak.

Dalam peraturan di Kode Etik Notaris Ikatan Notaris Indonesia (I.N.I) juga tidak disebutkan secara jelas dan terang mengenai kewajiban notaris untuk menerima penitipan sertifikat hak atas tanah dari para pihak oleh notaris maupun mengenai larangan notaris untuk menerima penitipan sertifikat hak atas tanah tersebut. Artinya, peraturan undangundang sama sekali tidak mengatur mengenai cara, kewajiban, atau tanggung jawab atas adanya penitipan sertifikat yang dilakukan. Penitipan yang terjadi selama ini biasanya hanya terjadi atas dasar kepercayaan dan kesepakatan dari para pihak kepada notaris tersebut.

\section{Akibat Penerimaan Titipan Sertifikat Hak atas Tanah oleh Notaris.}

Dalam kasus penitipan tanda bukti kepemilikan atas suatu benda para pihak tersebut, Notaris secara tidak langsung ikut berperan menjadi salah satu pihak dalam PPJB antara para pihak tersebut. Apabila dikaitkan dengan ketentuan dalam Pasal 52 ayat (1) Undang-Undang Nomor 30 Tahun 2004 
tentang Jabatan Notaris, keterlibatan Notaris menjadi salah satu pihak tersebut seharusnya dilarang. Selain itu, telah dijelaskan bahwa tugas notaris hanyalah membuat akta otentik dan melakukan kewenangan-kewenangan lain yang diatur dalam undang-undang.

Sementara itu, didalam undang-undang tentang jabatan notaris tidak ada satupun pasal yang memberikan kewenangan kepada notaris untuk menerima titipan sertifikat tanah dari para pihak apapun alasannya. Hal ini menegaskan bahwa notaris bukanlah suatu tempat atau lembaga penitipan sertifikat, namun hal tersebut hanyalah merupakan kebiasaan yang berlaku dalam praktik. Tetapi, di sisi lain memang dalam kasus seperti diatas pihak yang paling dapat dipercaya dan dianggap aman untuk dititipkan sertifikat tanah tersebut adalah notaris itu sendiri.

Akibat dari penerimaan titipan sertifikat hak atas tanah oleh notaris, baik sebagai jabatannya sebagai notaris atau bukan adalah sama, yaitu adanya perjanjian penitipan. Hal ini berarti berlaku ketentuan mengenai penitipan dalam Kitab Undang-Undang Hukum Perdata (KUHPerdata). Berdasarkan Pasal 1706 Kitab Undang-Undang Hukum Perdata, penerima titipan wajib memelihara barang titipan itu dengan sebaik-baiknya seperti memelihara barang-barang kepunyaan sendiri.

\section{Resiko dan Kasus Penerimaan Titipan Sertifikat Hak Atas Tanah oleh Notaris}

Penerimaaan titipan sertifikat hak atas tanah oleh notaris sebenarnya dapat menimbulkan resiko, baik bagi notaris itu sendiri maupun bagi para pihak. Bagi notaris, dengan menerima titipan sertifikat hak atas tanah dari para pihak sebenarnya merupakan beban bagi jabatannya. Disatu pihak, notaris tersebut harus bertindak sebagai penerima titipan dan harus menjaga sertifikat tanah tersebut dengan sebaik mungkin. Tetapi, apabila terjadi suatu hal yang tidak terduga yang menyebabkan sertifikat tersebut hilang, seperti terjadinya kebakaran, kebanjiran, atau kemalingan di kantor notaris tersebut yang menyebabkan sertifikat tanah tersebut musnah maka sebagai penerima titipan notaris harus bertanggung jawab sepenuhnya. Padahal, notaris tidak berkewajiban harus menyimpan sertifikat hak atas tanah tersebut.

Selain itu, apabila terjadi perkara di pengadilan yang berkaitan dengan sertifikat hak atas tanah tersebut, maka notaris dapat ikut terlibat dalam perkara tersebut. Notaris dapat disalahkan karena telah menyimpan sertifikat tanah tersebut, padahal berdasarkan peraturan yang berlaku itu bukanlah kewajibannya. Apalagi dengan adanya perubahan atas peraturan mengenai jabatan notaris, dimana dulu hakim harus meminta ijin terlebih dahulu apabila ingin memeriksa notaris yang bersangkutan, tetapi sekarang hakim tidak perlu meminta persetujuan lagi dari Majelis Pengawas Daerah. Karena itulah, maka sekarang notaris harus lebih berhati-hati dalam menjalankan jabatannya dan sebisa mungkin menghindari hal-hal yang membuatnya berhadapan dengan pengadilan. Dengan melakukan penerimaan penitipan sertifikat tanah para pihak yang belum diketahui apakah bermasalah atau tidak, maka notaris seperti menimbulkan resiko sendiri bagi jabatan yang ditanggungnya.

Sementara itu, bagi para pihak dengan menitipkan sertifikat tanah tersebut kepada notaris juga dapat menimbulkan resiko. Mungkin selama ini bagi semua orang, notaris adalah satu-satunya pihak yang paling tepat untuk dititipkan sertifikat tanah apabila terjadi perjanjian jual beli tanah, balik nama, dan lain-lain. Tetapi, dengan menitipkan 
sertifikat tanah tersebut kepada notaris sebenarnya tidak menjamin bahwa sertifikat tanah tersebut akan aman 100\% (seratus persen). Hal ini disebabkan karena meskipun ketentuan mengagunkan sertifikat tanah harus dilakukan oleh orang yang namanya tertulis dalam sertifikat tersebut, namun mutasi (pemecahan, balik nama, waris, hibah, jual beli) terhadap sertifikat tersebut dapat dilakukan tanpa sepengetahuan para pihak dengan permohonan mutasi sertifikat palsu. Dengan mutasi fiktif tersebut, sertifikat tanah para pihak dapat dijaminkan ke pihak lain dan para pihak tersebut telah kehilangan hak atas sertifikat tanahnya. Hal ini terbukti dengan adanya beberapa kasus yang terjadi akibat menitipkan sertifikat tanah di notaris.

Kasus yang pernah terjadi adalah kasus penggelapan sertifikat tanah yang dilakukan oleh seorang notaris Oky Annete Kahempong di Manado yang menyebabkan kerugian bagi para pihak. Selain itu, ada juga kasus penggelapan atas enam sertifikat tanah milik Suparjo yang dititipkan ke notaris Nurul Yaqin. Kasus yang paling baru adalah kasus artis Mandra yang merasa ditipu dengan notaris Sugeng Purnawan karena sertifikat tanah yang dititipkannya tiba-tiba sudah berpindah nama kepada orang lain.

B. HUBUNGAN KETERKAITAN ANTARA LARANGAN PENERIMAAN TITIPAN SERTIFIKAT HAK ATAS TANAH OLEH NOTARIS DENGAN KODE ETIK NOTARIS

\section{Kode Etik Notaris dalam Menjalankan Jabatannya.}

Kode etik notaris adalah norma-norma atau peraturan-peraturan mengenai etika, baik tertulis maupun tidak tertulis mengenai profesi notaris. Kode etik notaris ditetapkan oleh Ikatan Notaris Indonesia (I.N.I) dan disahkan oleh Kongres I.N.I yang diadakan di Surabaya dalam tahun 1972 dan kemudian diubah dan disusun dalam Kongres XIII yang diadakan dalam tahun 1987 di Bandung. Hubungan profesi notaris dengan masyarakat dan negara telah diatur dalam Undang-Undang Nomor 30 Tahun 2004 tentang Jabatan Notaris berikut peraturan perundang-undangan lainnya. Sementara hubungan profesi notaris dengan organisasi profesi notaris diatur melalui kode etik notaris.

Terdapat hubungan antara kode etik dengan Undang-Undang Nomor 30 Tahun 2004 tentang Jabatan Notaris. Hubungan pertama terdapat dalam Pasal 4 mengenai sumpah jabatan. Notaris melalui sumpahnya berjanji untuk menjaga sikap, tingkah lakunya dan akan menjalankan kewajibannya sesuai dengan kode etik profesi, kehormatan, martabat dan tanggung jawabnya sebagai notaris. Kode etik profesi notaris diterapkan dan ditegakkan oleh organisasi profesi. Adanya hubungan antara kode etik notaris dengan Undang-Undang Nomor 30 Tahun 2004 tentang Jabatan Notaris memberikan arti terhadap profesi notaris itu sendiri. Undang-Undang Nomor 30 Tahun 2004 tentang Jabatan Notaris dan kode etik notaris menghendaki agar notaris dalam menjalankan tugas jabatannya sebagai pejabat umum, selain harus tunduk pada Undang-Undang Nomor 30 Tahun 2004 tentang Jabatan Notaris juga harus taat pada kode etik profesi serta harus bertanggung jawab terhadap masyarakat yang dilayaninya, organisasi profesi (Ikatan Notaris Indonesia atau INI) maupun terhadap negara. Dengan adanya hubungan ini maka terhadap notaris yang mengabaikan keluhuran dari martabat jabatannya selain dapat dikenakan sanksi moril, ditegur, atau dipecat dari 
keanggotaan profesinya juga dapat dipecat dari jabatannya sebagai notaris.

\section{Hubungan Keterkaitan Penerim-aan Titipan Sertifikat Hak atas Tanah dengan Kode Etik Notaris.}

Penerimaan titipan sertifikat hak atas tanah tentu saja berkaitan dengan kode etik notaris. Dalam kode etik notaris, seorang notaris diwajibkan untuk menjaga kehormatan dan martabat profesinya dan juga perkumpulannya. Apabila notaris melakukan perbuatanperbuatan yang merugikan para pihak, maka itu akan berpengaruh pada kehormatan notaris itu sendiri. Selain itu, hal ini juga berdampak secara tidak langsung pada kehormatan perkumpulan notaris tersebut.

Dengan tindakan notaris untuk menerima titipan sertifikat atas tanah tersebut maka notaris seperti menambah resiko sendiri dalam melakukan pekerjaannya. Resiko yang bisa terjadi adalah apabila terjadi sesuatu hal yang tidak terduga yang menyebabkan sertifikat hak milik atas tanah tersebut hilang, seperti terjadinya kebakaran, atau kebanjiran di tempat kantor notaris. Selain itu, hal lain yang bisa terjadi adalah apabila ternyata sertifikat tanah tersebut bermasalah sampai ke pengadilan, maka notaris akan terlibat dalam urusan pengadilan tersebut, karena pada saat itu notaris adalah sebagai pemegang sertifikat hak milik atas tanah tersebut. Terjebaknya notaris karena penerimaan titipan sertifikat tanah sudah pernah menimbulkan akibat yang nyata, yaitu kasus notaris di Manado yaitu Notaris Oky Annete Kahempong yang terbukti melakukan penggelapan sertifikat tanah yang dititipkan kepadanya, sehingga notaris tersebut harus ditangkap dan berhadapan dengan hukum. ${ }^{2}$ Oleh karena itu, penerimaan titipan sertifikat hak atas tanah oleh notaris itu sebenarnya merupakan perbuatan yang mempunyai resiko yang sangat tinggi bagi notaris yang menerima penitipan tersebut maupun bagi pihak yang menitipkan sertifikat tanah tersebut.

Apabila resiko-resiko tersebut terjadi, maka hal tersebut dapat saja membuat nama notaris tersebut menjadi tercemar. Notaris tersebut dianggap lalai dalam melakukan pekerjaannya, dan dapat disalahkan karena melakukan sesuatu yang bukan kewajibannya sebagai seorang pejabat umum seperti yang diatur dalam undang-undang. Hal yang lebih buruk yang dapat terjadi adalah bahwa nama perkumpulan notaris juga dapat ikut tercoreng akibat perbuatan notaris untuk menerima titipan sertifikat atas tanah tersebut. Padahal, sebagai anggota dari sebuah perkumpulan sudah menjadi kewajiban seorang notaris untuk selalu menjaga nama baik perkumpulan dan hanya melakukan tindakan-tindakan yang sudah diatur jelas di dalam undang-undang dan kode etik notaris Indonesia.

\section{Sanksi Bagi Notaris yang Menyalah- gunakan Penitipan Sertifikat Hak atas Tanah dari Para Pihak}

Sampai sekarang memang belum ada aturan khusus mengenai perbuatan notaris yang menyalahgunakan penerimaan titipan sertifikat hak atas tanah dari para pihak, sehingga masih banyak perbedaan pendapat diantara para notaris berkaitan dengan penerimaan sertifikat hak atas tanah dari para pihak tersebut.

2 Fransisca Harry Gunawan, dkk. 2014. "Tanggung Jawab Yuridis Notaris PPAT Sebagai Pelaku Tindak Pidana Penggelapan terhadap Sertifikat Tanah yang Diserahkan Para Pihak". Artikel dalam Jurnal Ilmiah Magister Kenotariatan Universitas Udayana Volume 09, hlm.14. 
Apabila terjadi kasus perbuatan menyimpang yang dilakukan oleh notaris yang menerima penitipan sertifikat hak atas tanah, maka hal tersebut masuk ke dalam bidang pidana dan notaris dihukum berdasarkan aturan pidana yang berlaku dengan tuduhan penggelapan. Sementara, di bidang perdata sendiri, karena belum ada aturan yang jelas maka hal notaris tidak dapat dikenakan sanksi.

Apabila notaris melakukan perbuatan yang merugikan para pihak dari penerimaan titipan sertifikat hak atas tanah, maka hukuman yang didapat notaris lebih bersifat batiniah, yaitu hilangnya rasa tenang dan munculnya rasa bersalah. Selain itu, apabila perbuatannya tersebut menjadikan nama baiknya tercemar sehingga tidak dapat dipercaya lagi, maka mungkin notaris tersebut juga akan kehilangan jabatannya.

\section{PENUTUP}

\section{Kesimpulan}

Di dalam Undang-Undang Nomor 30 Tahun 2004 tentang Jabatan Notaris dan Undang-Undang Nomor 02 Tahun 2014 tentang Perubahan Atas Undang-Undang Nomor 30 Tahun 2004 tentang Jabatan Notaris tidak ada pasal yang menyebutkan secara tegas bahwa notaris berkewajiban untuk menerima atau menolak penerimaan sertifikat hak atas tanah dari para pihak. Tetapi, Pasal 52 ayat (1) Undang-Undang Nomor 30 Tahun 2004 tentang Jabatan Notaris, menyebutkan: "Notaris tidak diperkenankan membuat akta untuk diri sendiri, istri/suami, atau orang lain yang mempunyai hubungan kekelurgaan dengan notaris baik karena perkawinan maupun hubungan darah dalam garis keturunan lurus kebawah dan/atau ke atas tanpa pembatasan derajat, serta dalam garis ke samping sampai dengan derajat ketiga, serta menjadi pihak untuk diri sendiri, maupun dalam suatu kedudukan ataupun dengan perantaraan kuasa."

Apabila pasal tersebut dikaitkan dengan perbuatan notaris yang menerima penitipan sertifikat hak atas tanah dari para pihak, maka notaris dapat dianggap menjadi salah satu pihak. Karena itulah, maka peraturan mengenai penerimaan sertifikat hak atas tanah dari para pihak masih berupa kekaburan hukum. Banyak kasus yang terjadi karena adanya pelanggaran yang dilakukan oleh notaris atau para pihak yang menyebabkan kerugian, baik dari para pihak, notaris, bahkan sampai kepada perkumpulan notaris akibat penerimaan titipan sertifikat hak atas tanah tersebut. Jadi sudah seharusnya lah penerimaan titipan sertifikat tanah oleh notaris tersebut dilarang dan dibuat aturan khususnya oleh pemerintah.

Penerimaan sertifikat hak atas tanah oleh notaris tentu saja berkaitan dengan kode etik notaris. Dalam kode etik notaris, seorang notaris diwajibkan untuk menjaga kehormatan dan martabat profesinya dan juga perkumpulannya. Apabila notaris melakukan perbuatan-perbuatan yang merugikan para pihak akibat penerimaan sertifikat hak milik atas tanah tersebut, maka itu akan berpengaruh pada kehormatan notaris itu sendiri. Selain itu, hal ini juga berdampak secara tidak langsung pada kehomatan perkumpulan notaris tersebut. Karena penerimaan sertifikat hak atas tanah oleh notaris dari para pihak belum ada diatur secara jelas, maka hukuman yang didapat notaris apabila merugikan para pihak dengan perbuatannya tersebut lebih bersifat batiniah, yaitu hilangnya rasa tenang dan munculnya rasa bersalah. Selain itu, perbuatannya tersebut juga menjadikan nama baiknya tercemar sehingga tidak dapat dipercaya lagi, sehingga 
mungkin notaris tersebut juga akan kehilangan jabatannya.

\section{Saran}

1. Hendaknya pemerintah segera membuat atau menambah peraturan secara lebih rinci mengenai kewenangan dan/atau larangan notaris yang berkaitan dengan perbuatan notaris dalam penerimaan sertifikat hak atas tanah dari para pihak, sehingga tidak ada perbedaan pendapat lagi diantara kalangan profesi notaris mengenai boleh atau tidaknya notaris menerima penitipan sertifikat hak atas tanah dari para pihak.

2. Hendaknya perlindungan hukum bagi notaris, para pihak, dan perkumpulan notaris yang berkaitan dengan penerimaan penitipan sertifikat hak atas tanah dapat lebih ditingkatkan lagi serta konsekuensi hukum bagi para notaris yang melanggar peraturan dapat lebih diperjelas lagi sehingga bisa memberikan efek jera bagi pelakunya dan mencegah agar hal seperti itu tidak terulang lagi.

\section{DAFTAR PUSTAKA}

\section{Peraturan perundang-undangan}

Kitab Undang-Undang Hukum Perdata (KUHPerdata).

Undang-Undang Nomor 30 Tahun 2004 tentang Jabatan Notaris.

Undang-Undang Nomor 02 Tahun 2014 tentang Perubahan Atas Undang-Undang Nomor 30 Tahun 2004 tentang Jabatan Notaris.

Peraturan Pemerintah Nomor 40 Tahun 1996 tentang Hak Guna Usaha, Hak Guna Bangunan, dan Hak Pakai atas Tanah.
Peraturan Pemerintah Nomor 24 Tahun 1997 tentang Pendaftaran Tanah.

\section{LITERATUR}

Adjie, Habib. 2008. Sanksi Perdata dan Administratif terhadap Notaris sebagai Pejabat Publik. Bandung : Refika Aditama.

Anshori, Abdul Ghofur. 2009. Lembaga Kenotariatan IndonesiaPerspektif Hukum dan Etika. Yogyakarta : UII Press.

Beekun, Rafik Issa. 2004. Etika Bisnis Islami. Yogyakarta : Pustaka Pel-ajar.

Budiono, Herlien. 2013. Kumpulan Tulisan Hukum Perdata di Bidang Kenotariatan. Bandung : PT. Citra Aditya Bakti.

Budiono, Herlien. 2014. Dasar Teknik Pembuatan Akta Notaris. Bandung: PT. Citra Aditya Bakti.

Febrizha Avrendha, Wishnu. 2008. "Peranan Notaris dalam Pembuatan Akta Pengikatan Jual Beli Hak Atas Tanah". Tesis Universitas Airlangga Surabaya : Program Studi Magister Kenotariatan Fakultas Hukum Universitas Airlangga.

Harry Gunawan, Fransisca dkk. 2014. "Tanggung Jawab Yuridis Notaris PPAT Sebagai Pelaku Tindak Pidana Penggelapan terhadap Sertifikat Tanah yang Diserahkan Para Pihak". Artikel dalam Jurnal Ilmiah Magister Kenotariatan Universitas Udayana Volume 09.

Harahap, Yahya. 2014. Hukum Acara Perdata. Jakarta : Sinar Grafika.

Lubis, Suhrawardi K. 2012. Etika Profesi Hukum. Jakarta: Sinar Grafika.

Magnis-Suseno, Franz. 1991. Etika Dasar Masalah-Masalah Pokok Filsafat Moral. Yogyakarta : Kanisius.

Muchsin. 2011. "Kedudukan Notaris dan Akta Notaris di Hadapan Penegak 
Hukum". Makalah disajikan pada Acara Pembekalan dan Penyegaran dalam Rapat Pleno Pengurus Pusat yang Diperluas di Mataram (Lombok).

Muhammad, Abdulkadir. 1997. Etika Profesi Hukum. Bandung : PT. Citra Aditya Bakti.

Muzakkar, T. 2009. "Perbandingan Peranan Dewan Kehormatan dengan Majelis Pengawas Notaris dalam Melakukan Pengawasan setelah Keluarnya UndangUndang Nomor 30 Tahun 2004". Tesis Universitas Sumatera Utara : Program Studi Magister Kenotariatan Fakultas Hukum Universitas Sumatera Utara.

Nico. 2003. Tanggungjawab Notaris Selaku Pejabat Umum. Yogyakarta :Center for Documentation and Studies of Business Law.

Prakoso, Abintoro.2015. Etika Profesi Hukum Telaah Historis, Filosofis dan Teoritis Kode Etik Notaris, Advokat, Polisi, Jaksa dan Hakim. Surabaya : LaksBang Justitia.

Santoso, Urip. 2010. Pendaftaran dan Peralihan Hak atas Tanah. Jakarta: Kencana.

Setiawan, Wawan. Diktat Ciri-Ciri yang Harus Dimiliki dan Unsur yang Harus Dipenuhi Bagi Seorang Notaris Ideal dan Profesional. Surabaya.

Sidharta. 2006. Moralitas Profesi Hukum,

Suatu Tawaran Kerangka Berpikir. Refika Aditama

Simanjuntak, P.N.H. 2009. Pokok-Pokok Hukum Perdata Indonesia. Jakarta: Djambatan.

Sofwan, Sri Soedewi Masjchoe. 2000. Hukum Perdata: Hukum Benda. Yogyakarta : Liberty.
Soegondo, R. Notodisoerjo. 1982. Hukum Notariat di Indonesia, Suatu Penjelasan. Jakarta: Rajawali.

Soekanto, Soerjono dan Sri Mamudji. 2010. Penelitian Hukum Normatif (Suatu Tinjauan Singkat). Jakarta: PT. Raja Grafindo Per-sada.

Sumaryono. 1995. Etika Profesi Hukum, Norma-norma bagi Penegak Hukum. Yogyakarta : Kanisius.

Sumaryono, E. 2003. Etika Profesi Hukum. Yogyakarta : Kanisius.

Sunur, Wildan Anshari. 2011. "Penyimpanan Sertifikat Tanah oleh Notaris dalam Pembuatan Akta Pengikatan Jual Beli Tanah". Tesis Universitas Airlangga Surabaya : Program Studi Magister Kenotariatan Fakultas Hukum Universitas Airlangga.

Susanto, Budi. 1992. Nilai-nilai Etis dan Kekuasaan Utopis. Yogyakarta : Kanisius. Tedjosaputro, Liliana. 1995. Etika Profesi Notaris, dalam Penegakan Hukum Pidana. Yogyakarta : Bigraf Publishing.

Tobing, GHSL. Sari Kuliah Peraturan Jabatan Notaris.

Wiranata, I Gede A.B. 2005. Dasar-Dasar Etika dan Moralitas (Pengantar Kajian Etika Profesi Hukum). Bandung : Citra Aditya Bakti.

\section{INTERNET}

Anggraeni, Fitria. Etika Profesi SeorangNotaris. www.academia.edu/6276509/ BAB_I_ MAKALAH_NOTARIS. Diakses pada tanggal 02-/06/2015.

Anonim. Akta Otentik Dalam Hukum Positif Indonesia. https://72legalogic. wordpress. com /20-09/03/-23/akta-otentik-dalam- 
hukum-positif-indonesia/. Diakses pada tanggal 27/04/2015.

Bouty, Sarah. 2014. Etika Profesi-Analisa Kasus Kode Etik Notaris. www.academia. edu/7267706/E-TIKA_PROFESI Analisia_Kasus_Kode_Etik_Notaris. Diakses pada tanggal 20 Desember 2015.

Damang. 2013. Akta Otentik dan Akta Bawah Tangan. www.negarahuk-um.com/hukum/ akta-otentik-dan-akta-bawah-tangan. html. Diakses pada tanggal 08/06/2015.

Galih. Pengertian dan Fungsi Kode Etik.https:// pakdalih.wordpress.com/2009/04/07/ pengertian-dan-fungsi-kode-etik/. Diakses pada tanggal 22/04/2015.

$\mathrm{N}$, Sora. Pengertian Kode Etik dan Tujuannya Lengkap.www.peng-ertianku. net/2015/02/pengertian-kode-etik-dantujuannya-len-gkap.html.

Perdana, Andrean. 2013. Pengertian Profesi,Profesional, Profesionali-sme, Profesionalitas, Profesion-alisasi.www. andreanperdana.com/2013/03/pengertianprofesi-profesional.html?m=1. Diakses pada tanggal 30 Agustus 2015.

Purnomo, Herdaru. Mengintip Layanan Safe Deposit Box di Bank.m.det-ik.com/ finance/read,2012/06/21/071426/1946 705/5/mengintip-layanan-safe-depositbox-di-bank. Diakses pada tanggal 28/09/2015.

Shobirin, Rochmat. 2015. Sertifikat Tanah.m.suaradesa.timesindonesia.co.id/ baca/97/20150417/153456/pentingnyasertifikat-tanah-bagi-masyarakat.html.

Tobing, Leteza. Notaris sebagai PenerimaTitipan.m.hukumonline.com/klinik/ details/1t51afbd8b62

e5/notaris-sebagai-penerimatit-pan. Diakses pada tanggal 20/08/2015. 